Max-Planck-Institut für demografische Forschung

Max Planck Institute for Demographic Research

Konrad-Zuse-Strasse 1 - D-18057 Rostock - GERMANY

Tel +49 (0) 3812081 - 0; Fax +49 (0) 3812081 - 202;

http://www.demogr.mpg.de

MPIDR WORKING PAPER WP 2010-027

SEPTEMBER 2010

\title{
How East and West Germans finance their lifecycle consumption: Evidence from NTA
}

Fanny Annemarie Kluge (kluge@demogr.mpg.de)

This working paper has been approved for release by: Michaela Kreyenfeld (kreyenfeld@demogr.mpg.de), Acting Deputy Head of the Laboratory of Economic and Social Demography.

(c) Copyright is held by the authors.

Working papers of the Max Planck Institute for Demographic Research receive only limited review. Views or opinions expressed in working papers are attributable to the authors and do not necessarily reflect those of the Institute. 


\title{
How East and West Germans finance their lifecycle consumption: Evidence from NTA
}

\author{
Fanny Annemarie Kluge*
}

August 30, 2010

\begin{abstract}
This paper seeks to identify the differences in income sources between East and West Germany and their relative importance over the lifecycle by applying the National Transfer Accounts methodology. In our analysis we make use of the almost unique historical setting the previously divided country provides to study how differing institutional arrangements shape the economic lifecycle. For the younger age groups, we find differences between East and West. These differences are mainly due to the high public consumption per capita in the East, as estimates of private consumption do not show a large degree of variation between the two regions. Our results further show that the income sources differ the most among the elderly, as the East Germans who lived under socialism, did not accumulate assets, and relied entirely on public pensions. Nevertheless, an increase in asset income could be observed in recent decades.
\end{abstract}

\footnotetext{
${ }^{*}$ Max Planck Institute for Demographic Research, Konrad-Zuse-Str. 1, 18057 Rostock, Germany Email: kluge@demogr.mpg.de, Phone 0049-381-2081-210.
} 


\section{Introduction}

Over the course of their lives, individuals experience remarkably long periods of dependency (when consumption exceeds production) during childhood and old age (Lee et al., 2006). Consumption during the two dependent stages that occur at the beginning and the end of life must to be financed by alternative sources, such as private or public transfers or assets. The monetary flows needed to finance this dependency are large, with intergenerational transfers amounting to about one-half of national income (Mason, 2005). The alternative means of financing consumption over the lifecycle, the ratio of public to private transfers, and the role played by assets in financing retirement for the elderly, are issues of great concern to policy makers. This is especially true for countries where public pensions play a prominent role as an income source for the elderly, and the aging of the population calls into question the sustainability of the existing social security transfer channels. In the context of the aging German welfare state it is crucial for us to gain a to better understanding of the differences in the transfer mechanisms between East and West, as these transfers represent a significant reallocation of resources, not only by age groups, but also across regions.

As a result of historical events ${ }^{1}$, the two parts og Germany experienced virtually opposite political and socio-economic environments. Over a period of 40 years, while West Germany was developing a functioning market economy, the socialist ideology in the East prevented a significant differentiation in wages (Franz and Steiner, 2000). For the elderly, the pension system in the East provided public pensions that were nearly equal in size. Moreover, the egalitarian system in the East did not produce a large number of homeowners, nor luxury goods to invest where available. Because saving for retirement ${ }^{2}$ was not necessary, and there were no incentives to save, most GDR citizens did not accumulate assets. Although the public pension system in the West was granting generous public pensions, and these pensions crowded out savings to an extent, West Germans nearly always sought to accumulate assets as well. ${ }^{3}$ Today, in the wake of the most recent pension reforms, German citizens are witnessing cutbacks in the public pension system. Due to these reductions, the need to boost savings rates for retirement will become increasingly urgent in the near future. Because of the differing amounts of time they had to participate in the market economy, pensioners in the two parts of the country began to plan for retirement under very different conditions. In this study, we will try to quantify this variation.

Many previous studies have compared the economic and social conditions, or the degrees of transfer dependency, in the East and the West. Gender role differences affect

\footnotetext{
${ }^{1}$ After the Second World War Germany, was divided into an eastern part under Soviet authority, and a western part governed by the Western Allies over a period of 40 years.

${ }^{2}$ See Modigliani and Brumberg (1954); Feldstein (1976); Modigliani (1986).

${ }^{3}$ The mean amount of capital that was bequeathed in 2002 was more than four times higher for an individual from the West than from the East (Kohli et al., 2006b).
} 
labor market issues even today. The East German government expected, and needed, to have both men and women participating in the labor force: whereas in West Germany's socially conservative welfare state, it was understood that women would perform unpaid domestic labor, while the men became the breadwinners (Rosenfeld et al., 2004, p. 104). This meant that there was greater gender equality in the East German labor market, with high levels of female employment ${ }^{4}$ and long working hours even for mothers [ibid.]. In addition, the lower wages meant that most families needed two incomes (Nickel, 2003). The restructuring of individual lives that took place after reunification yielded a high number of jobseekers who could not find suitable positions in the new labor market. Although additional off-the-job training was offered, the situation remained serious (Lechner, 1999). The severity of the restructuring the labor market, and its effects on individuals, were immense. One out of three workers, or about three million people, lost their jobs after 1989 (Dornbusch et al., 1992, p. 239). The large shifts into new positions or unemployment resulted in a sharp drop in female labor force participation and high unemployment rates in the East (Figure 1). Income differences persisted even after reunification as can be seen in the National Accounts (for 2003, the compensation of employees per capita in the East only reached 75 percent of Western levels) and were due in part to the lower levels of productivity in the former GDR, which have been well-documented (Burda and Hunt, 2001; Akerlof et al., 1991; Barrell and Te Velde, 2000). Nevertheless, wages in the East increased substantially at the beginning of the 1990s, as did the wage inequality (Franz and Steiner, 2000).

The direct transfer of resources from the West to the East for infrastructure improvements is a subject that has been studied extensively. The "German Reunification" fund redistributed 160.7 billion German marks to the East between 1990 and 1994 (Wagner, $2001)^{5}$. Subsequently, the new Länder were included in the financial equalization scheme between the federal government and the Länder. During the period 1995 - 2005 (Solidarpakt I) about 204 billion (20 billion annually) euros were transferred to the East in an effort to bring the Eastern infrastructure up to Western levels (Wagner, 2001, p. 46). The amount transferred to the Eastern region exceeded five percent of West German GDP (Raffelhüschen and Walliser, 1999, p. 277). The solidarity surcharge, additional payments of the fiscal equalization fund (Länderfinanzausgleich), and federal supplement grants (Bundesergänzungsabgabe) still play important roles in the fiscal budgets of local governments in the East. The "Solidarpakt II", which was established in 2005, seamlessly followed the earlier one, and will operate until 2019. According to Seitz (2006, p. 29), the direct transfers to the East currently amount to 10 billion euros each year, and will grad-

\footnotetext{
${ }^{4}$ In 1989, the female labor force participation rate was 89 percent in the East and only 56 percent in the West (Rosenfeld et al., 2004, p. 111).

${ }^{5}$ The transfers to the East amounted to 18 percent of GDP if Berlin is included: if Berlin is not included the share rises to 26 percent of GDP.
} 


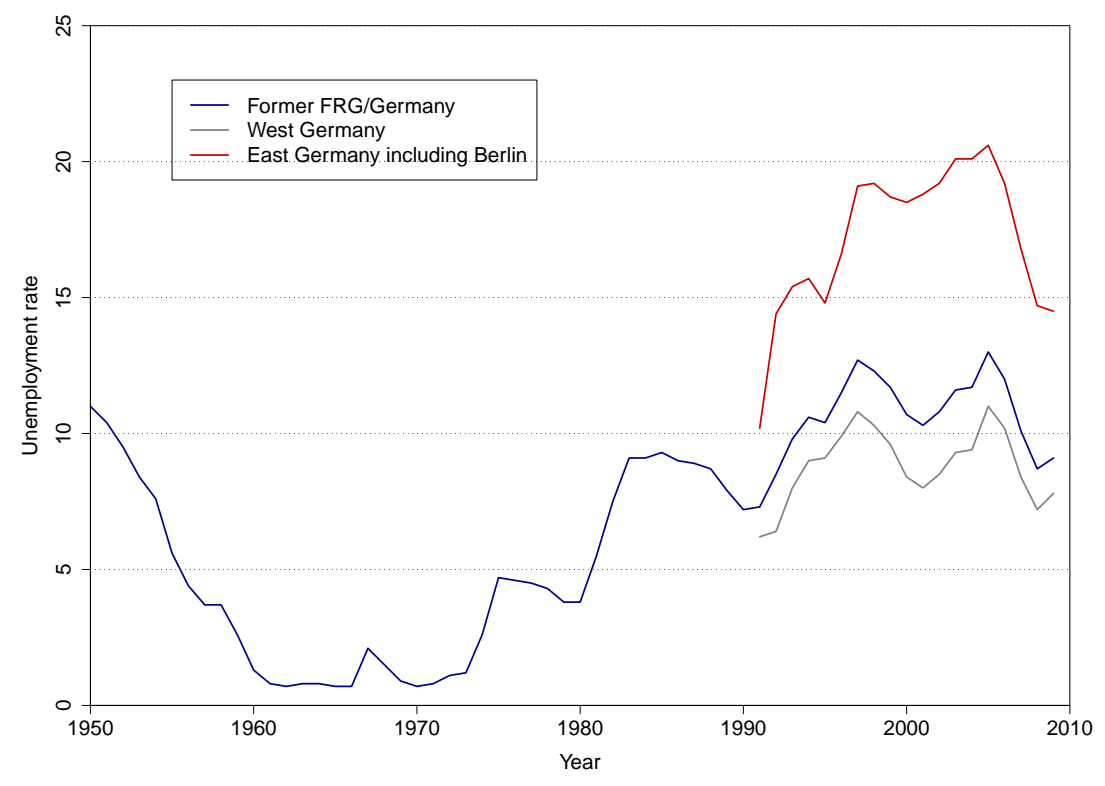

Figure 1: Unemployment rate

Source: Bundesagentur für Arbeit 2010

ually taper off until they reach three billion euros in 2019, after which the "Solidarpakt II" will expire.

In addition to these direct monetary transfers, transfers via the social security system, especially pensions, flowed from West to East. The East German system granted retirement benefits which were neither tied to the level of income, nor to the duration or size of contributions. A unitary monthly amount was distributed to the individual based on the number of years the person spent in employment, with amounts ranging from a basic provision (330 eastern German Marks) to a maximum of 470 eastern German Marks (Steffen, 2002). After reunification the conversion of East German pensions was very generous and the values for the East were multiplied by an annual factor that resulted in pensioners in the East receiving approximately the same amounts as pensioners in the West, despite the fact that wages and pensions were much lower in the GDR. Indeed due to high labor force participation rates of women (Sinn, 2002) and long working histories, East Germans had higher per capita pension values than their West German counterparts. In 2003, the social security budget in the East witnessed a shortfall of 60 billion euros. The high per capita pension values are expected to decrease when the younger cohorts enter retirement age as they experienced severe disruptions in their working histories.

This paper seeks to identify the differences in income sources between East and West Germany and their relative importance over the lifecycle. To answer this question we will make use of the National Transfer Account (NTA) methodology, which builds upon 
the work of Samuelson (1958), Diamond (1965), Willis (1988), Lee (1994), and Bommier and Lee (2003). The NTA methodology allows us to investigate differences in the complete individual economic lifecycle, as well as transfer patterns between East and West. This approach should enable us to deepen our understanding about how institutional arrangements affect the profiles. We will examine the differences in the individual economic lifecycle of East and West Germans, including differences in private and public transfers, labor income, and asset-based reallocations. While a number of other studies have looked at various aspects of the lifecycle and differences between East and West, this paper takes a more inclusive approach, rather than focusing on only one part of the story. We take into account all the possible agents such as families, the state or NPISH's and relate the micro behavior of these agents to nationally representative macro controls. ${ }^{6}$ By taking this approach, we are able to consistently capture all the important variables affecting each individual agent over his lifecycle in a cross-sectional setting.

The organization of the paper is as follows. In Section 2, we will present the materials and methods used to estimate the lifecycle differences in East and West Germany. Section 3 will present the results for the three main stages of life - children, prime age adults and the elderly - for the two regions of interest. The consequences of population aging for the public transfer system in Germany will be the subject of the fourth section, and the final section will consist of a brief summary.

\section{Materials and Methods}

The estimates are based on National Accounts and population data, both provided by the Federal Statistical Office (FSO) and the German Income and Expenditure Survey (Einkommens- und Verbrauchsstichprobe, or EVS). Macro control totals are provided by the statistical offices of the German Länder (Statistische Ämter der Länder, 2008). ${ }^{7}$ The macro control totals are used as an anchor to adjust the micro profiles to fit National Accounts estimates. Table 1 provides the numbers used for estimation. Total public consumption figures for East and West Germany are available in the National Accounts. Unfortunately, a problem arises because the estimates for education, health and "other" are unavailable in greater detail. Therefore, the shares found at the national level were assumed to hold in both regions.

The population estimates are available in one-year age groups provided by the German

\footnotetext{
${ }^{6}$ For all variables of interest, the micro foundation comes from the Income and Expenditure survey, and the adjustment is based on the macro controls from the National Accounts, and is thus nationally representative.

${ }^{7}$ This is a joint publication of the 16 statistical offices of the German Länder, the Federal Statistical Office and the Bürgeramt, Statistik und Wahlen, Frankfurt a. M. The statistical offices of the 16 Länder report their numbers in a manner that allows us to separate the main economic indicators for East and West.
} 
Table 1: The macro controls for East and West Germany 2003 in billion euros and per capita values

\begin{tabular}{|l|r|r|r|r|}
\hline & Aggregate & & Per Capita & \\
\hline & West & East & West & East \\
\hline Population & 65 618 912 & 16912759 & & \\
\hline Labor income & $\mathbf{1 0 4 3 . 6 2}$ & $\mathbf{2 0 2 . 2 7}$ & $\mathbf{1 5 ~ 9 0 4}$ & $\mathbf{1 1 ~ 9 5 9}$ \\
\hline Earnings income & 957.56 & 189.27 & 14592 & 11191 \\
Self-employment income & 86.06 & 12.99 & 1311 & 768 \\
\hline Public consumption & $\mathbf{3 2 7 . 4 2}$ & $\mathbf{8 9 . 4 2}$ & $\mathbf{4 ~ 9 8 9}$ & $\mathbf{5 ~ 2 8 7}$ \\
\hline Public education consumption & 51.53 & 14.07 & 785 & 831 \\
Public health consumption & 107.07 & 29.24 & 1631 & 1728 \\
Public other consumption & 168.82 & 46.11 & 2572 & 2726 \\
\hline Private consumption & $\mathbf{9 0 5 . 8 8}$ & $\mathbf{1 8 8 . 3 1}$ & $\mathbf{1 3} \mathbf{8 0 5}$ & $\mathbf{1 1} \mathbf{1 3 4}$ \\
\hline Private education consumption & 1.51 & 8.15 & 124 & 89 \\
Private health consumption & 5.08 & 37.14 & 566 & 300 \\
Private housing consumption & 6.01 & 39.80 & 606 & 355 \\
Private durables consumption & 18.44 & 81.45 & 1241 & 1090 \\
Private other consumption & 157.27 & 739.33 & 11267 & 9299 \\
\hline Public cash transfer inflows & $\mathbf{3 4 8 . 7 2}$ & $\mathbf{1 0 6 . 7 2}$ & $\mathbf{5 3 1 4}$ & $\mathbf{6 ~ 3 1 0}$ \\
\hline Old age pensions & 209.85 & 61.17 & 3198 & 3616 \\
Unemployment/social benefits & 53.33 & 23.28 & 812 & 1376 \\
Other social security & 55.84 & 15.30 & 1303 & 3301 \\
\hline Outflows on labor & 551.72 & 103.11 & 8407 & 6096 \\
\hline Income and property taxes & 184.45 & 24.06 & 2810 & 1422 \\
Social contributions & 367.27 & 79.05 & 5596 & 4674 \\
\hline Outflows (NTA Classification) & $\mathbf{6 6 7 . 6 5}$ & $\mathbf{1 2 8 . 3 4}$ & $\mathbf{1 0 ~ 1 7 4}$ & $\mathbf{7 5 8 8}$ \\
\hline Taxes on consumption & 130.81 & 27.19 & 1993 & 1607 \\
Taxes on labor & 445.86 & 88.13 & 6794 & 5211 \\
Taxes on assets & 90.97 & 13.02 & 1386 & 769 \\
\hline
\end{tabular}

Source: VGR der Länder, author's own calculations 
Federal Statistical Office, and are based on an extrapolation of census data. The last census conducted in the former Federal Republic of Germany was in 1987, and the final census in the former German Democratic Republic was carried out in 1981. In addition to this data, we also used publications of the Ministry of Health and Education in cases in which the National Accounts and FSO statistics do not provide sufficient information.

The microlevel survey data were obtained from the EVS of 2003. The EVS is conducted every five years by the FSO, and is based on a representative quota sample of Germany's private households. The EVS includes a detailed account of income by source, consumption by type, saving flows, and asset stocks by portfolio category. The EVS of 2003 includes around 50,000 households made up of some 127,000 individuals. The waves from 1993 onward include not only data from the former Federal Republic, but also a sample from the former German Democratic Republic. The survey is representative of households with a monthly net income of less than 18,000 euros. The EVS does not include very wealthy households (70,000 of 38.1 million households), persons with no permanent residence, or the institutionalized population. (For a methodological overview, see Statistisches Bundesamt (2005). For three months, participating households kept a detailed book of household accounts that covered every kind of potential income and expenditure.

The National Transfer Accounts methodology ${ }^{8}$ will be used to construct the estimates. The flow account identity is given by

$$
\underbrace{Y^{l}(a)+Y^{a}(a)+\tau^{+}(a)}_{\text {Inflows }}=\underbrace{C(a)+S(a)+\tau^{-}(a)}_{\text {Outflows }},
$$

where $Y^{l}(a)$ is the labor income, $Y^{a}(a)$ is the asset income, and $\tau^{+}(a)$ are the transfers received at each corresponding age a. $C(a), S(a)$, and $\tau^{-}(a)$ are consumption, savings and transfers paid at each age. The inflows need to equal the outflows on the aggregate level of Germany. Rearranging the equation 1 leads to

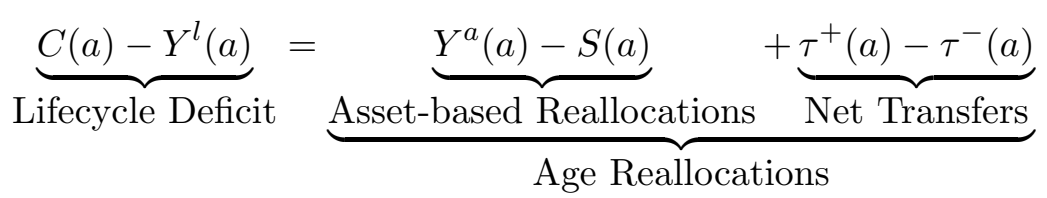

(Mason et al., 2008). In the separate LCD estimates for East and West, we allow for flows between the two parts of the country, with the East receiving subsidies, and benefiting from public expenditures in the form of public transfers, such as unemployment benefits and pensions.

A closer look at the reallocation mechanisms will enable us to determine to what extent the lifecycle deficit is financed via public or private transfer channels for the people

\footnotetext{
${ }^{8}$ For further information see www.ntaccounts.org.
} 
aged 45 and above, to identify the leading institutions that reallocate between the age groups, and to understand how these mechanisms work differently in the East and in the West. The age profiles used to compute the NTA (e.g. for income, consumption, public or private transfers, and asset income) are drawn from survey data, and are then smoothed and adjusted to the corresponding macro control. Data on private consumption of education and health is available at the household level, but when this data are needed on the individual level, a method similar to the one developed by Attanasio et al. (1999) is employed. All other forms of consumption are allocated based on an allocation rule developed by Deaton and Paxson (1997). Our equivalence scale is more continuous, but is similar (Lee et al., 2006). For public consumption the information needed can be obtained from the Ministry of Education and the Ministry of Health.

Due to the data format, Berlin is included entirely in the East profiles. ${ }^{9}$ This adjustment was necessary, as the macro numbers can only be obtained by including West Berlin in the Eastern part of the country. Using the microsurvey presents no difficulties as in all of the 16 states, each household's place of residence is distinguishable; West Berlin is simply coded as East. It should be noted that the variable identifying the region a person lives in is the current region. People employed in the West may have originally come from the former GDR. In order to evaluate how severe this might bias the estimates, the income by age was compared using the current region from the EVS and the SOEP data, and contrasted to income values applying the former region where the person lived before reunification. The differences were small, and hence no additional efforts were made to further investigate the issue. The public transfer part was estimated directly from the survey, and all the necessary in- and outflows were drawn from the EVS, as before.

Private transfers had to be adjusted differently. Estimates for inter-household transfers caused additional problems. For all of Germany, they were estimated and balanced with the private transfers to the rest of the world (ROW). When this setting is applied, the inter-household inflows needed to equal the inter-household outflows, plus the balance from ROW. In the case of the East-West estimates, we unfortunately do not know the value of inter-household transfers crossing the former border. Nor do we have information about the actors making or receiving transfers. Instead, we used the original estimates of inter-household transfers for East and West. This allowed us to calculate the intra-family transfers. Finally, we calculated the asset-based reallocations, including asset income and savings information, as the residual.

\footnotetext{
${ }^{9} 18$ percent of the eastern German population live in Berlin, and the city's GDP accounts for 23 percent of total Eastern GDP.
} 


\section{Lifecycle Results for East and West Germany}

National Transfer Accounts are designed to track all of the possible monetary inter-age flows in an economy. It follows that the main driving forces of the profiles are the extent to which individuals pursue paid employment, receive public assistance, or invest in assets. Figure 2 illustrates the main income sources in East and West Germany by age, 13 years after the reunification. The "other social security profile" includes people who receive unemployment benefits, who are on on partial retirement ("Altersteilzeit") or who collect basic social welfare payments. A relatively high percentage share of people aged 50 and over in the East have left the labor market and must bridge the gap to pension income. Twenty percent of the elderly receive unemployment benefits, and another 10 percent participate in partial retirement programs. The values are more than twice as high in the East as in the West. Pensioners in the East live almost entirely on public pensions: they have virtually no other income source. In the West, the corresponding percentage is only 80 percent, and a greater number of pensioners additionally accumulated assets. Using the concept of the lifecycle deficit, we hope to gain insight into how the dependent stages of life, when consumption exceeds labor income, are financed. The different roles played by pensions and social security as income sources over the lifecycle suggests that there are also differing patterns of financing consumption in the East and West. Differences that are related to gender roles, the value assigned to unemployment benefits, or the importance of asset-based reallocations, are certainly reflected in the accounts.

The nominal profiles of the lifecycle deficits for East and West are depicted in Figure 3. Consumption is decomposed into education, health, housing, durables, and "other": where "other" is the dominant item, including food and rent for housing. The latter accounts for 80 percent of private expenditures in both regions. The listed remaining consumption items are less important. The shapes of the profiles are therefore the same. Younger people consume education, while the elderly consume health care. Nevertheless, interesting differences can be found. Per capita private education expenditures are twice as high in the West as in the East, although the percentage share is low. The average expenditures in East Germany are nearly equally distributed across all age groups from five to 25, while in the West, a tendency towards higher expenditures for secondary and tertiary education can be observed. Health care expenditures are also twice as high in the West as in the East, amounting to 650 euros for a 70-year old in the East, compared with 1,200 euros in the West. Similar differences can be seen in the imputed rental values of owner-occupied housing. While the discrepancy is not too large among 20-40 year olds, the gap widens substantially from age 50 onwards. Only the share of durables consumed in the East reaches 75 percent of Western values. Total private consumption for both regions shows the double-hump-shaped pattern resulting from household economies of 


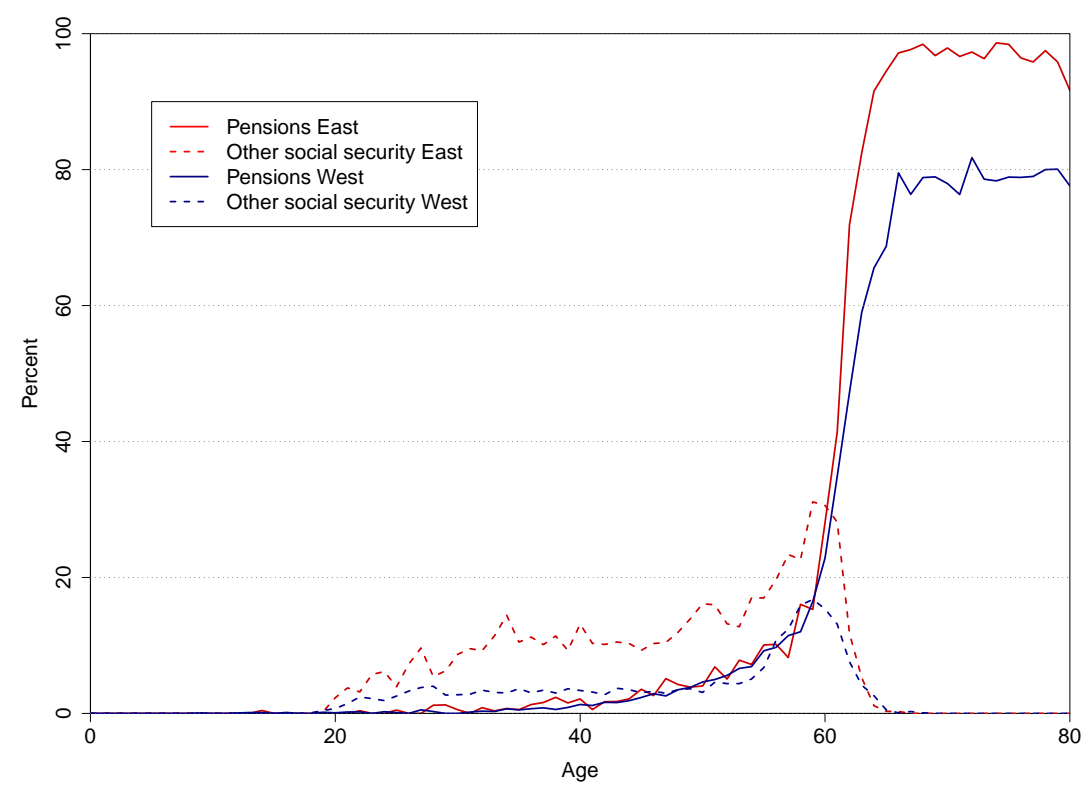

Figure 2: Income source by age, East and West 2003

Source: SOEP 2003

scale, though this pattern is less pronounced in the East. For the youngest ages, the gap between total private expenditures in the East and in the West is narrow, and only adds up to 1,000 euros. At the first peak in expenditures, which occurs in the early thirties, the gap widens to 3,000 euros. Meanwhile, the biggest gap can be seen between the 60year-olds in the two countries, with the difference in expenditures per capita amounting to 4,500 euros. A study of these diverging consumption patterns was also conducted by Jenke and Lebok (2009). They find the eastern Germans to be more price sensitive than their Western counterparts. Among higher earners, the gap closes. So the general picture is therefore quite similar. Education and health care expenditures are low, and only housing results in a higher per capita profile because of higher homeownership rates in the West. If we look at the expenditures for luxury items, such as jewelry or eating out, we find that values for the West are about one-third higher than in the East. Nonetheless, the differences are much smaller for holiday expenditures, and East Germans even tend to spend more, on average, than the West Germans on holidays.

Public consumption per capita is highest for school-age children and for the oldest old. The adjustment of public consumption was made based on the shares of German public consumption items in 2003, as detailed public consumption information cannot be obtained at the sub-national level. The Eastern and Western macro control totals for public consumption are used as an anchor. Far higher expenditures per capita for education, partly due to the dramatic decline in the TFR in the early 1990s, and partly 


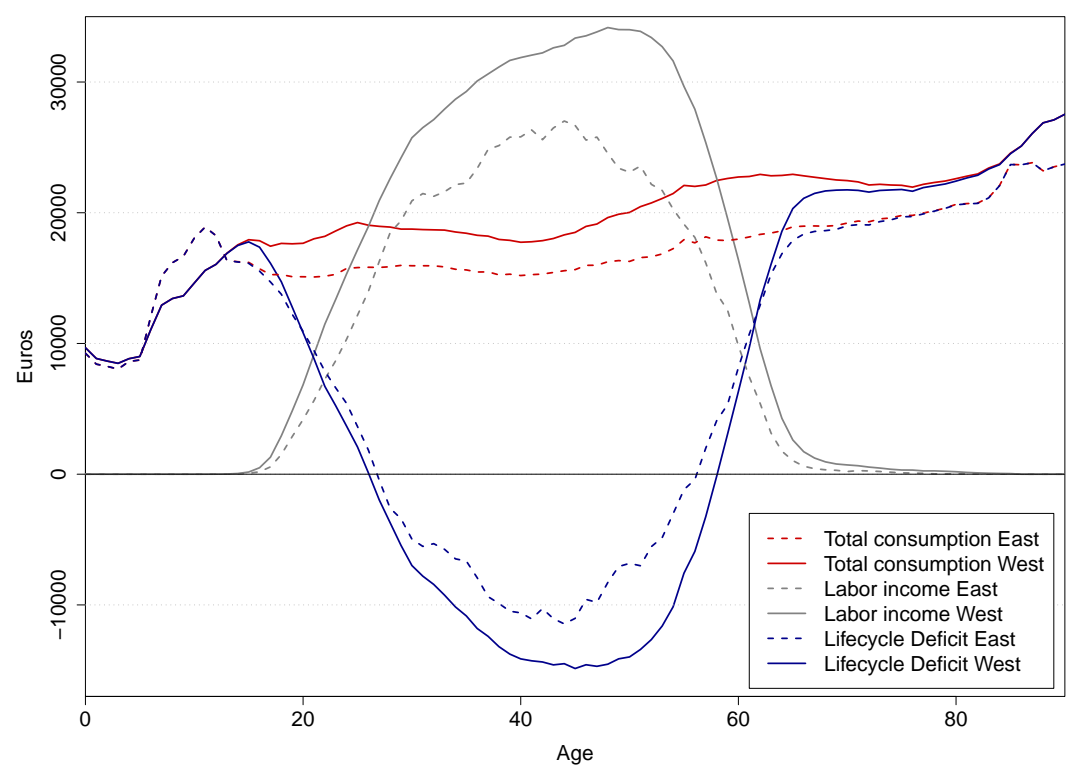

Figure 3: The nominal lifecycle deficit for East and West Germany in euro in 2003

Source: EVS 2003, National Accounts 2003, author's own calculations

because of large expenditures on education, are recorded in the East. In all of the East German Länder, per capita spending on education exceeds five percent of GDP (Statistisches Bundesamt, 2007), which is considerably higher than in the West German Länder, such as Bavaria (3.4 percent of GDP) and Baden-Württemberg (3.8 percent of GDP). This is all the more remarkable considering that a smaller proportion of the population are of school-age. Public health expenditures are almost identical, and the difference in public consumption cannot be attributed to health. Other public consumption is allocated equally, and also does not account for the higher nominal values in the East. The strong role played by the welfare state in the East is, as mentioned earlier, a product of history. Even today, the percentage of jobs in the public sector is higher in the East (Franz and Steiner, 2000). For this reason, the total public consumption profile mainly differs for children of school age, where the value for the East exceeds the value for the West by about 3,000 euros. For all other age groups, the nominal values are comparable.

To construct the lifecycle deficit, we add labor income to our estimates. The profiles show the usual working life pattern, beginning with an increase at about age 18 . The peak ages differ, with the East reaching the highest values in the early forties, and the peak in the West following some years later. On average, Easterners earn on average 7,000 euros per capita per year less than Westerners. Both of the profiles decrease early, but the slope in the Western profile is steeper, whereas in the East, a higher share of the elderly participate in alternative programs, such as partial retirement. 
Figure 4 presents the normalized lifecycle deficit for East and West Germany in $2003^{10}$. The surplus period starts at age 27 in both regions, and it ends by age 56 in the East, two years earlier than in the West. This period is shorter and the surplus is higher across all age groups. The lifecycle deficits for all of the dependent age groups in the East exceed the deficits in the West by about 10 percentage points. The values are even higher for the age groups attending school in the East. As wages are lower in the East, a 10-year-old in that part of Germany consumes 74 percent of the average income of people aged 30-49; while in the West the corresponding share is only 47 percent. A similar trend can be seen for the elderly population: a 70-year-old person in the East consumes 79 percent of the average income of a prime-age adult, compared with 70 percent in the West. Over the age of 80 East German pensioners consume more than 90 percent (relative to a prime-age adult's income), versus only around 80 percent in the West. The gap narrows only for the oldest old, mainly due to the increased importance among this age group of public transfers, including health care and long-term care, and a relative decrease in private consumption.

Focusing only on the normalized lifecycle deficit for private consumption minus labor income (while disregarding public consumption), Eastern and Western profiles are almost identical. The main driving force of the higher deficit in the East is public consumption, which was raised intentionally at the beginning of the 1990s to allow for a more rapid convergence (with especially large amounts devoted to building a comparable infrastructure) of the two parts of the country. Since then, expenditures have been growing, rather than declining.

Upon examining the surplus period, we find an interesting, and almost similar pattern in the East and in the West in the age range 27 to 40, although the Eastern profile is more volatile, and not as smooth as its Western counterpart. This is presumably due to the disruption and gaps in the employment biography that occurred more frequently in the East, especially in the years directly after reunification, when many individuals had to change jobs (Dornbusch et al., 1992). Although the NTA show a cross-section, the profile of ages 30 to 45 in Figure 4 might appear to indicate that the gap between the two regions narrows for the younger cohorts, especially concerning labor market issues. After age 45, we observe a sharp increase in the lifecycle deficit in the East. This is due to the high transfer dependency of the elderly in the East, as shown in Figure 2. The lifecycle deficit on an individual basis differs substantially. Whereas in the former FRG, the LCD adds up to 2,907 euros per capita, the value for the former GDR area amounts to 4,488 euros. If we multiply the LCD with the age structure, the lifecycle deficit for Germany totals to 265 billion euros. This is the part of consumption that is not paid for by earnings or income from self-employment. The Eastern share of the deficit is 28 percent $(75.5$ billion, or 22.8 percent of Eastern GDP), even though only 20 percent of the population lives in

\footnotetext{
${ }^{10}$ The LCD is normalized to the labor income of a prime-age adults income between 30 to 49 .
} 


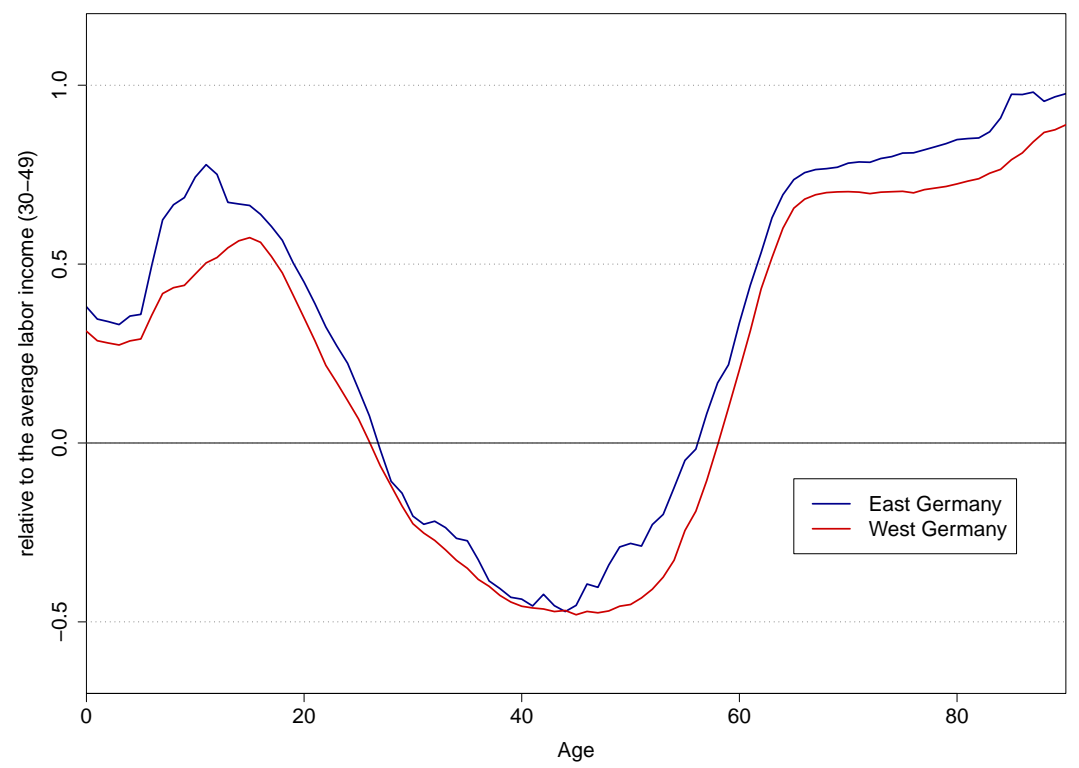

Figure 4: The normalized lifecycle deficits for East and West Germany, 2003

Source: EVS 2003, National Accounts 2003, author's own calculations

the former GDR.

The higher lifecycle deficit for the East, together with the knowledge that the Eastern part of the country is more dependent on transfers, points to the crucial role of the public sector. The decomposition of public transfer inflows is pictured in Figure 5 . Pensions follow the same age profile, though they are a little higher in the East, because virtually everyone in that part of the country was employed prior to reunification. Long working histories and higher participation rates for women compensate for lower wages. Unemployment benefits and the basic social security profile increase with age, and are twice as high in the East. Other forms of social security consist of family benefits, such as maternity leave and child allowances. The amount per capita for the two regions is similar, with only the peak age differing, due to the younger age at family formation in the East.

Figure 6 compares the total transfer in- and outflows. Per capita total public inflows are approximately comparable, with slightly higher values in the East. For younger ages, in-kind transfers for education are important, while the elderly receive public pensions. Extensive social security expenditures transferred to the East cannot be supported on the basis of the per capita inflow profile. The main difference appears on the public transfer outflow side. The revenues of government are highly dependent on paid employment. The main sources are labor and income taxes and social contributions; together, they constitute two-thirds of total revenues. As wages are lower and unemployment rates are higher in 


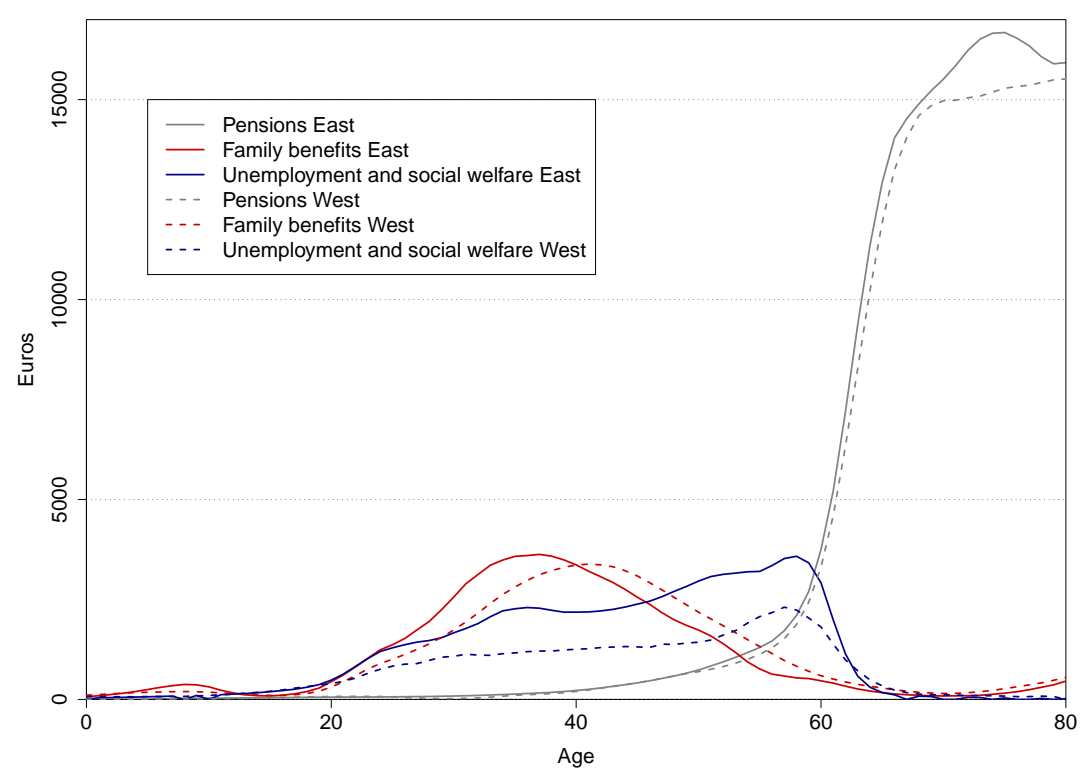

Figure 5: Public transfer inflows for East and West 2003

Source: EVS 2003, National Accounts 2003, author's own calculations

the East, the public transfer outflows are well below the Western numbers, and are thus the net public transfers. The difference adds up to more than 5,000 euros per capita for a 45- to 50-year-old individual. Aggregating the public transfer outflows (128 billion) and inflows (in-kind: 89 billion euros, and cash 106 billion euros), we observe that the social security budget in the East comes up 67 billion euros short. In contrast, the deficit for the West amounts to only 8.5 billion euros. The direct annual flows amounted to 20 billion euros in the past and are of the same magnitude even today. Indirect flows crossing the former border are more than three times the direct flows. Although the "Solidarpakt II" fund will gradually melt off and expire in 2019, the indirect flows are of a permanent nature.

Private transfers complete the first part of the age reallocations. In both parts of Germany, private transfers are downward, from the old to the young. Until around age 30, people are net recipients. The inflows for Western children and younger adults are about 15 percent higher than for their Eastern compatriots, as their private consumption is higher. When net private transfers turn negative, they remain especially high during the stage of parenthood, and are negligible at about age 60 . Thereafter, the transfers again increase when individuals reach the phase of grandparenthood. The flows of private transfers between prime-age adults are higher in the West, as dependent spouses need financial assistance more frequently. The strict downward flow of private transfers in both regions is especially surprising, as East German pensioners rely almost exclusively 


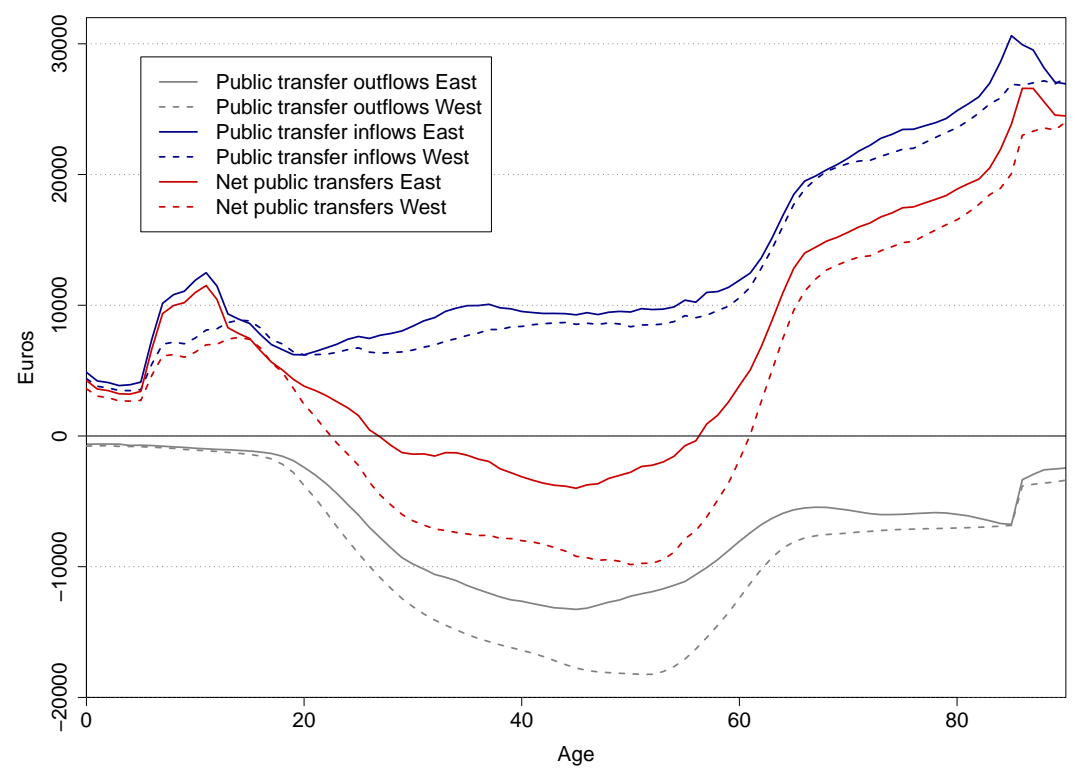

Figure 6: Public transfer in- and outflows for East and West 2003 Source: EVS 2003, National Accounts 2003, author's own calculations

on public pensions, with assets playing a minor role role in their portfolios. Nonetheless, the percentage amount transferred to the next generation is comparable. Private transfers are imputed from the EVS microsurvey. By definition, inflows have to match the outflows. Total private transfers add up to 332 billion euros in the West and to 63 billion euros in the East. The difference per capita is about 1,400 euros.

In the remaining part of this section, we will examine the three main stages of the lifecycle separately. The income sources presented so far include labor income from earnings and self-employment, as well as public and private transfers. In addition, the importance of asset-based reallocations for each age group will be presented, although they are mainly of concern for the elderly.

\section{Children}

We will start with the first stage of the human lifecycle: namely, how the needs of children are financed. Figure 8 presents in- and outflows for "Max Mustermann" (the German equivalent of "John Doe") in the East and the West for three stages over the synthetic lifecycle ${ }^{11}$. For the young, the state plays a more important role in the East, with half of consumption being financed by the family, and the other half by the state (in the West, it is 60 percent to 40 percent). Assets do not play a crucial role in this age group, as it is assumed that only the household head possesses any wealth. Transfers to the average child on a per capita basis are almost the same in both regions, and amount

\footnotetext{
${ }^{11}$ Please note that the estimates are cross-sectional.
} 
to slightly over 270,000 euros. Transfers of this amount are given to a child over a 20-year period. In the East, the transfers from the government are even slightly higher than the private transfers, while in the West, private transfers dominate. This is mainly due to the fact that private consumption is higher in the West, and the share of children is higher as well. As a percentage share of the labor income of an average 20-59-year-old, the transfers to children are comparable in the two regions (East: 16 percent, West: 14 percent).

\section{Adults}

In a welfare state that provides education (and health care) for the young, and public pensions and health care for the elderly, the working age population faces a double burden. They not only have to support their own children ant the elderly; they are also supposed to save for their own retirement, especially in the wake of the latest pension reforms in Germany.

On a per capita basis, private transfers of working-age individuals as a percentage of labor income do not differ between East and West, and amount to about eight percent of labor income. As the private transfer inflows for the average child are twice as high, we find that two prime-age adults pay for one child. The dramatic decline in the TFR in recent decades reduces the burden of the working-age generations. Until the 1970s, a couple had to support at least two children. Today, with many couples having just one child, and a high percentage of women remaining childless, an increasing number of primeage adults make transfers to children only via the public sector. The double burden for the working-age individual is mainly imposed by the government, which also forces them to pay for the elderly. Outflows of public transfers are about three times higher for West German individuals.

Asset income - including all kinds of capital income, and for example the imputed rental value of owner-occupied housing - of a prime age adult in the West is about 10 times higher than in the East. The shape of the asset-based reallocation profile (asset income minus savings) is similar in the two regions (Figure 7), and tends to be low for individuals until around age 50. We then observe a sharp increase until around age 65 . Then income starts to decrease moderately, but remains positive until the last observation at age 90. However, the curve in the East is shifted to a lower level, producing negative and more volatile values up to about age 45 . Over the same ages, individuals in the West have positive estimates. That is probably due to the fact that, while East Germans save a portion of their income, but they do not have considerable capital transfer inflows, as is the case in the West.

\section{The elderly}

The differences in income sources are most pronounced for the elderly. In particular, the importance of assets relative to public transfers varies in the two parts of Germany, and is an artifact of history. After World War II, when West Germany was developing a 


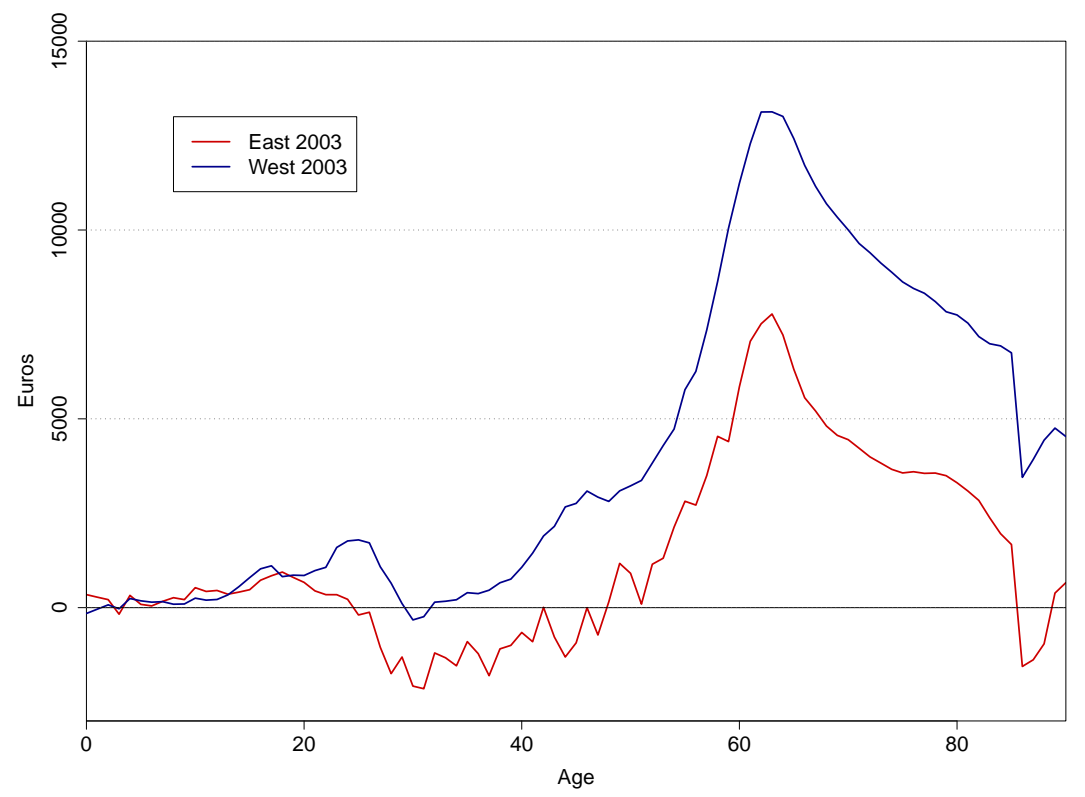

Figure 7: Asset-based reallocations, East and West 2003

Source: EVS 2003, National Accounts 2003, author's own calculations
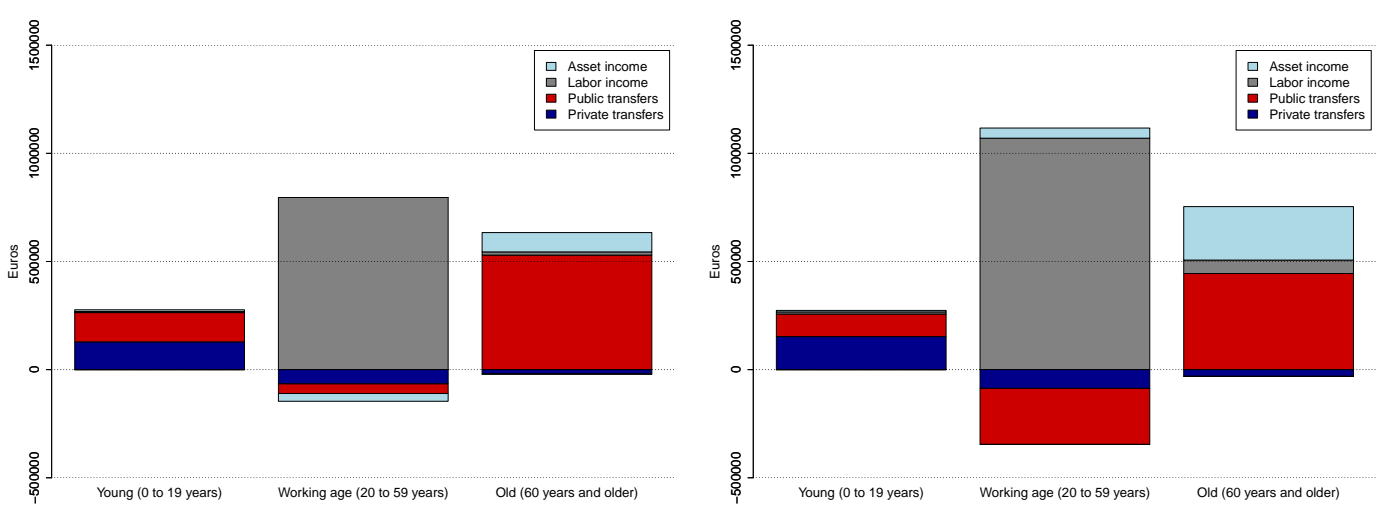

Figure 8: Financing the LCD: Max Mustermann alias John Doe for East (left) and West (right) in 2003

Source: author's own calculations based on German NTA estimates 
functioning market economy, the East was designed as a state-owned, centrally planned economy. Because socialist ideology did not allow for a high differentiation of wages (Franz and Steiner, 2000), wages were similar for all individuals. While GDR citizens did not have sufficient income to save, the egalitarian provision of public pensions made saving for retirement unnecessary. Homeownership rates also varied greatly between the East and West. In the East, two types of homeownership existed: socialist property and individual property. Rents were fixed, and due to disincentives to owning a home imposed by the government, homeownership decreased from 62 percent in 1971 to 41 percent in 1989 (Ebinger, 2005). Today, 25 percent of housing in the East and 40 percent of housing in the West is owner-occupied (Ibid.).

Table 2 illustrates the income sources used to finance the retirement of the elderly in East and West Germany over time. It shows the relationship of family transfers, public transfers, and asset returns for Germans aged 65 and above in aggregate values for two points in time. As can also be seen in Figure 8, the table shows that the elderly realize negative values for private transfers, which means that they are net givers. Regardless of the size of public transfers, German pensioners still redistribute a share of their income to the succeeding generations. Unfortunately, the profiles are aggregates, so it is unclear whether inter-vivos transfers are given to their children or grandchildren. In percentage terms, the difference between the two regions is small, which is in line with Kohli et al. (2006a).

The extent to which assets and public transfers are used to finance retirement differs substantially between the East and the West. In the East, public transfers make up to slightly more than 85 percent of retirement income, compared to two-thirds in the West. The public transfer inflows per capita are even higher for an East German individual, which is mainly due to the higher public pensions per capita. Pension entitlements are greater among East Germans as a result of their long working histories, and the very high female labor force participation rates in the East before 1990.

Assets play a more important role in the West (40 percent) than in the East (20 percent), and include capital and interest income. Capital income includes the operating surplus of corporations and NPISHs, the operating surplus of households, and the capital share of mixed income and taxes on production. This inclusive approach taken by the NTA accounts for the differences in the relative importance assigned to assets, relative to other studies ${ }^{12}$. Eastern Germans invest in bonds and stocks at lower rates than West Germans. The same holds true for life insurance contracts (Börsch-Supan and Eymann, 2002).

Table 2 also includes information about the changes that occurred between 1993 and

\footnotetext{
${ }^{12}$ Reil-Held (2002) found that 80 percent of income in the West consists of public transfers, compared to NTA estimates of 66 percent.
} 
2003. It is noteworthy that the role of assets for the elderly doubled in the East within 10 years. After reunification, their share amounted to only seven percent; while 10 years later, it was about 20 percent. The percentage of income transferred to the next generation slightly increased in the East, whereas it decreased in the West. Assets already played a significant role for the Western elderly in 1993. Nevertheless, in both regions, the lion's share of income is redistributed from the public sector, although the share is decreasing in both regions.

Table 2: The income sources of the elderly over time

\begin{tabular}{|l|r|r|r|}
\hline Region and Year & Public Transfers & Assets & Private Transfers \\
\hline East 2003 & $85.2 \%$ & $20.5 \%$ & $-5.7 \%$ \\
\hline West 2003 & $65.1 \%$ & $40.8 \%$ & $-6.9 \%$ \\
\hline East 1993 & $98.5 \%$ & $4.2 \%$ & $-2.7 \%$ \\
\hline West 1993 & $79.2 \%$ & $33.4 \%$ & $-10.3 \%$ \\
\hline
\end{tabular}

Source: various sources, author's own calculations

Having discussed the importance of the income sources over the lifecycle for the East and West separately, we now address the question of how population aging will affect the transfer system in the future.

\section{The impact of population aging for the transfer system}

The aging of the population is of major concern in Germany, as it is among the countries that are farther along in the demographic transition. For decades, the fertility rates have been very low, and have been accompanied by increases in life expectancy. In the East, population aging is even more pronounced than in the West, as outmigration of young people has increased the pace of aging. According to Heiland (2004), there were two outmigration waves. The first wave occurred directly after the fall of the Berlin Wall in 1989, when 3.7 percent of the population from the former GDR emigrated. Until the mid-1990s, the annual outmigration rates were about one percent, and then rose again in the late 1990s, hitting a peak of 1.64 percent outmigration in 2001 (Heiland, 2004, p. 176). While the first wave was mainly due to the uncertainty of future events, the second wave can be attributed to economic developments. The people who left the East were mainly young skilled adults, and a higher proportion were female (Kempe, 1999; Hunt, 2000; Mai, 2004). These emigrants left behind a population who were farther along on the aging trajectory.

Figure 9 shows the dependency ratios for East and West Germany from 1950 to 2050. In the middle of the last century, we find that the youth dependency ratio was higher than 

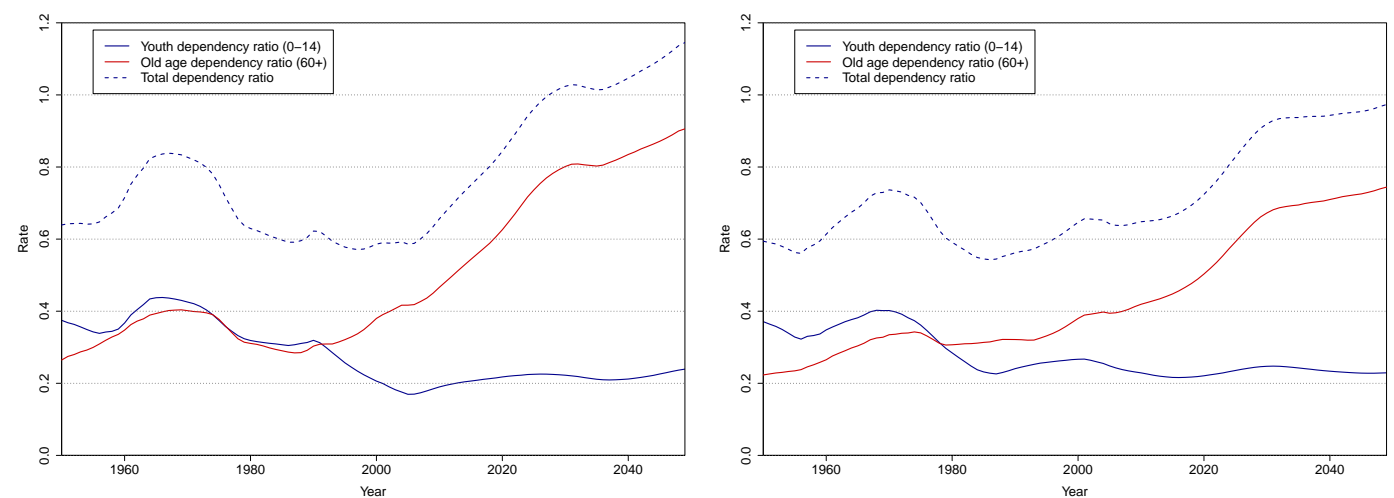

Figure 9: Dependency ratios 1950-2050, East (left) and West (right)

Source: author's own calculations based on population estimates (Federal Statistical Office)

the old age dependency ratio. The reversal of this relationship took place in the late 1970s in the West, and about 10 years later in the East. Since then, the youth dependency ratio has declined, and has reached a stable value of around 20 percent. At the same time, the old age dependency ratio has been increasing rapidly, and is predicted to reach 80 percent in the East and 70 percent in the West in 2030.

Figure 10 depicts the economic support ratios for the two regions of interest over the same time period. The age profiles of consumption, income, and transfers are assumed to stay constant over time. At the same time, the demography is developing in line with the 12th coordinated population projection (Statistisches Bundesamt, 2009). The shapes of the two curves are similar, but the East is always lower than the West. Population aging will affect the East more severely, and the support ratio will drop below 60 percent in 2020. Based on the NTA estimates, we can assume that the interstate flows that go indirectly from the West to the East through the social security system will continue to make up a substantial proportion of the income of East Germans long after the direct flows to the East end in 2019.

In Table 3, we show the results of a very simple static experiment. We use the consumption and income profiles of the NTA in 2003 to predict the gap between consumption and labor income in the future for the young and the elderly. This experiment only takes into account the demographic changes. ${ }^{13}$. Thus, the lifecycle deficit will increase in both regions over time. The increase is more pronounced in the West than in the East, as the East is already aging quite rapidly, while the West will experience the same phenomenon at an accelerating pace. The values for 2020 and 2030 are quite high, as the baby boomers reach retirement age. The lifecycle deficit of the young will decrease substantially over the

\footnotetext{
${ }^{13}$ The demography develops according to the 12 th coordinated population projection (Statistisches Bundesamt, 2009)
} 


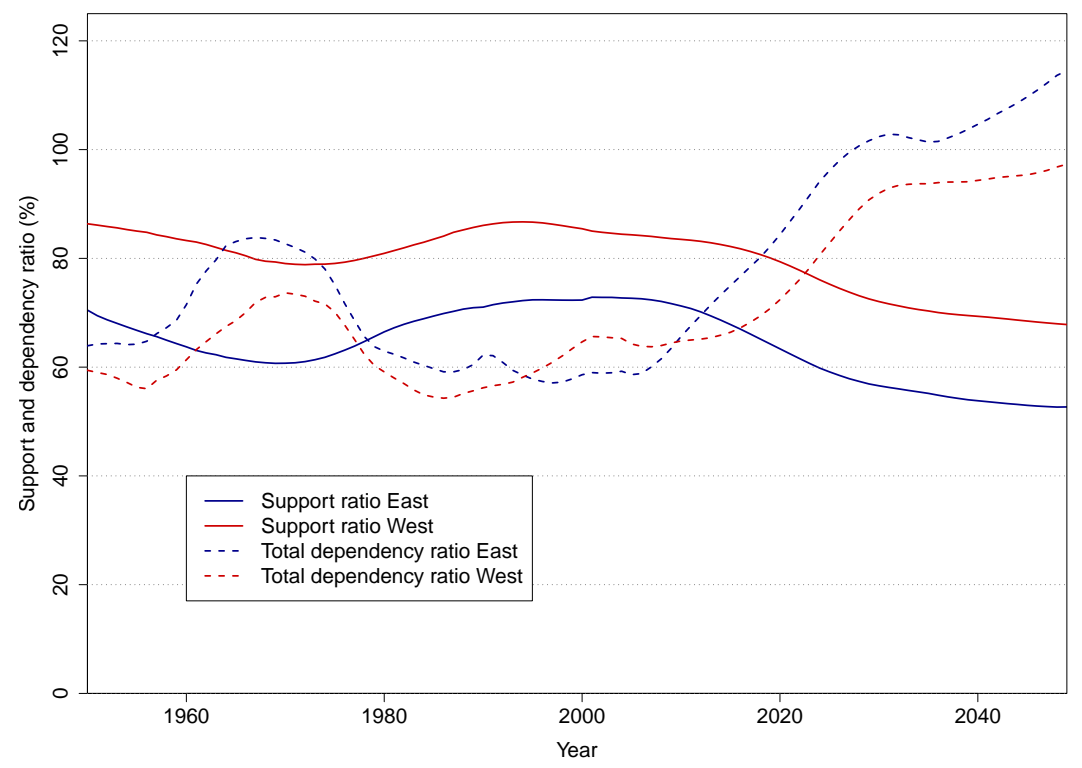

Figure 10: Economic support ratios and total dependency ratios for East and West 2003 Source: Federal Statistical Office, NTA estimates, author's own calculations

next 20 years, as a lower number of children will require financial support. At the same time, the lifecycle deficit of the elderly is expected to develop in the opposite direction. This increase will be entirely due to the greater number of elderly people using public health care. Currently, we do not expect the lifecycle deficit to increase rapidly for the oldest old in Germany, as it is the case in Japan or the US. If the per capita lifecycle deficit behaves like this in the future, the values will be even higher. Another reason why the lifecycle deficit is growing is that a decreasing number of people of working age will produce a surplus.

The income sources available to the dependent age groups are likely to change under these conditions. As the number of people of working age rapidly declines, government inflows are likely to decrease. With fewer public resources available, the share of private transfers for children is likely to increase. At the same time, the elderly will have to cope with decreasing public pensions, and will therefore have to decrease consumption or increase savings.

The demand for wealth to finance the coming lifecycle deficit is growing rapidly. In the future, the financing strategy of social security will need to be reformed. Social security contributions from labor only are going to decrease, since a smaller number of people will be of working age. Hence, it will be necessary to reduce the burden on labor, and to look for alternative tax revenues, such as taxes on consumption. 
Table 3: The lifecycle deficit of children and the elderly in comparison

\begin{tabular}{|l|r|r|}
\hline Variable and Year & East & West \\
\hline Total LCD 2003 & 75.5 bn & 189.7 bn \\
\hline Total LCD 2020 & 95.1 bn & 250.1 bn \\
\hline Total LCD 2030 & 105.7 bn & 330.7 bn \\
\hline \hline Children 2003 & 44.4 bn & 193.6 bn \\
\hline Children 2020 & 34.3 bn & 149.9 bn \\
\hline Children 2030 & 31.2 bn & 143.1 bn \\
\hline \hline Elderly 2003 & 59.6 bn & 250.4 bn \\
\hline Elderly 2020 & 78.6 bn & 301.3 bn \\
\hline Elderly 2030 & 88.6 bn & 358.8 bn \\
\hline
\end{tabular}

Source: various sources, author's own calculations

\section{Conclusion}

In this paper, we have presented estimates of income sources in East and West Germany, and have examined their importance in financing consumption at each stage of life. These income sources include labor income, public transfers, private transfers, and assets. The relative importance of these income sources over the lifecycle differs by age and region. As expected, the profiles vary with respect to the role of the state between the two "countries". If we look only at private consumption, the profiles resemble one another. This means that, relative to their labor income, East Germans do not consume disproportionately more than West Germans. As soon as public consumption is included, however, the gap widens substantially. The shapes of the profiles resemble each other, but the lifecycle deficit reaches higher levels in the East. This trend is especially pronounced for the people in education.

On a nominal per capita basis, the public transfer inflows are not much higher for East than for West Germans. Nevertheless, the net public transfers are far below the German average. The lower employment levels and lower wages in the East result in both a transfer surplus period that is eight years shorterin the East, and in transfer outflows that are substantially lower. The annual flows from West to East amount to about 70 billion euros redistributed through the social security system. This figure is seven times the size of the direct flows of 2003. Whereas the direct transfer flows to the East will expire in 2019 , the flows through the social security system are of a more permanent nature, and will not decrease substantially due to the unfavorable age structure of the Eastern population. Generally, we find that the importance of public transfers in financing consumption is higher in the East for all dependent age groups, but especially for the elderly.

Private transfers move strictly downwards to the younger generations, and, as a share 
of income, pensioners in the East and the West transfer approximately the same amounts. The amounts transferred in the East increased from 1993 to 2003, which indicates that East German pensioners are feeling better off after reunification, and are able to give a share of their resources to their children and grandchildren. At the same time, the reverse is true for the West. Here the amount transferred to the younger generations has almost halved, which probably reflects pension cuts over this period.

The main difference we observe is in the role played by of assets in the portfolios of elderly people. While assets make up to 39 percent of the income of West Germans over the age of 65 , the corresponding share in the East is only 16 percent. This is, of course, explained by the fact that the elderly in the East were unable to build up capital stock in the former GDR. In addition, homeownership rates are lower in the East, which has resulted in lower shares of imputed rental value for owner-occupied housing. Over the time period 1993 to 2003, we can observe signs of convergence. Whereas in 1993, assets played virtually no role in the sources of income of the East German elderly, the share increased by 10 percentage points over the decade. During the same time, the importance of assets in the West only grew by 7 percentage points. 


\section{References}

Akerlof, G., Rose, A., Yellen, J., and Hessenius, H. (1991). East Germany in from the Cold: The Economic Aftermath of Currency Union. Brookings Papers on Economic Activity: Macroeconomics, pages 1-87.

Attanasio, O. P., Banks, J., Meghir, C., and Weber, G. (1999). Humps and Bumps in Lifetime Consumption. Journal of Business \& Economic Statistics, 17(1):22-35.

Barrell, R. and Te Velde, D. W. (2000). Catching-up of East German labor productivity in the 1990s. German Economic Review, 1(3):271-297.

Bommier, A. and Lee, R. (2003). Overlapping generations models with realistic demography. Journal of Population Economics, 16(1):135-160.

Börsch-Supan, A. and Eymann, A. (2002). Household Portfolios in Germany. In Guisi, L., Haliassos, M., and Jappelli, T., editors, Household Portfolios. MIT Press, Cambridge, MA.

Burda, M. C. and Hunt, J. (2001). From Reunification to Economic Integration: Productivity and the Labor Market in Eastern Germany. Brookings Papers on Economic Activity, 2001(2):1-71.

Deaton, A. S. and Paxson, C. H. (1997). The Effects of Economic and Population Growth on National Saving and Inequality. Demography, 34(1):97-114.

Diamond, P. (1965). National Debt in a Neoclassical Growth Model. The American Economic Review, 55(5):1126-1150.

Dornbusch, R., Wolf, H., and Alexander, L. (1992). Economic Transition in Eastern Germany. Brookings Papers on Economic Activity, 1992(1):235-272.

Ebinger, A. (2005). Differences in patterns of home ownership in the New and the Old Federal States. Master's thesis, Hochschule für Wirtschaft und Umwelt NürtingenGeislingen.

Feldstein, M. (1976). Social Security and Saving: The Extended Life Cycle Theory. The American Economic Review, 66(2):77-86.

Franz, W. and Steiner, V. (2000). Wages in the East German Transition Process - Facts and Explanations. German Economic Review, 1(3):241-269.

Heiland, F. (2004). Trends in East-West German Migration from 1989 to 2002. Demographic Research, 11(7):173-194. 
Hunt, J. (2000). Why do people still live in East Germany? NBER Working Paper, Working Paper 7564.

Jenke, S. and Lebok, U. (2009). Von Aufbau Ost zu Aldi-Ost. Deutsch-deutsches Konsumverhalten nach 16 Jahren Einheit. In Cassens, I., Luy, M., and Scholz, R., editors, Die Bevölkerung in Ost und Westdeutschland, pages 334-367. VS Research.

Kempe, W. (1999). Bildungsstruktur der Ost-West-Migration: Humankapitalverlust Ostdeutschlands gestoppt. Wirtschaft im Wandel, 15(5):19-23.

Kohli, M., Künemund, H., Motel, A., and Szydlik, M. (2006a). Families Apart? Intergenerational Transfers in East And West Germany. In Arber, S.; Attias-Donfut, C., editor, The myth of generational conflict. The familiy and the state in ageing societies, pages 88-99. Routledge, London.

Kohli, M., Künemund, H., Schäfer, A., Schupp, J., and Vogel, C. (2006b). Erbschaften und ihr Einfluss auf die Vermögensverteilung. Vierteljahrshefte zur Wirtschaftsforschung, $75(1): 58-76$.

Lechner, M. (1999). Earnings and Employment Effects of Continuous Off-the-Job Training in East Germany after Unification. Journal of Business $\&$ Economic Statistics, 17(1):7490.

Lee, R. (1994). The Formal Demography of Population Aging, Transfers, and the Economic Life Cycle. In Martin, L. G. and Preston, S. H., editors, Demography of Aging, pages 8-49. National Academy Press Washington, DC 1994.

Lee, R., Lee, S., and Mason, A. (2006). Charting the Economic Life Cycle. In A. Prskawetz, D. E. B. and Lutz., W., editors, Population Aging, Human Capital Accumulation, and Productivity Growth, pages 208-237. Population and Development Review, New York, Population Council.

Mai, R. (2004). Abwanderung aus Ostdeutschland. Strukturen und Milieus der Altersselektivität und ihre regionalpolitische Bedeutung. Frankfurt/Main (Peter Lang).

Mason, A. (2005). An Overview of National Transfer Accounts. National Transfer Account Working Paper. www.ntaccounts.org.

Mason, A., Lee, R., Tung, A., Lai, M., and Miller, T. (2008). Population Aging and intergenerational transfers: introducing age into National Accounts. Developments in the Economics of Aging. NBER Working Paper Series.

Modigliani, F. (1986). Life Cycle, Individual Thrift, and the Wealth of Nations. The American Economic Review, 76(3):297-313. 
Modigliani, F. and Brumberg, R. (1954). Utility Analysis and the Consumption Function: an Interpretation of Cross-section Data. In Kurihara, K., editor, Post-Keynesian Economics. NJ. Rutgers University Press, New Brunswick.

Nickel, H. (2003). The future of female employment: a gendered gap in political discourse. In Kolinsky, E. and Nickel, H., editors, Reinventing gender: women in Eastern Germany since unification, volume XII, pages 31-52. London: Frank Cass.

Raffelhüschen, B. and Walliser, J. (1999). Unification and Aging in Germany: Who Pays and When. In Auerbach, A., Kotlikoff, L., and Leibfritz, W., editors, Generational Accounting Around the World, NBER series, pages 277-297. Chicago University Press.

Reil-Held, A. (2002). Die Rolle intergenerationaler Transfers in Einkommen und Vermögen älterer Menschen in Deutschland. Mannheim: Universität Mannheim.

Rosenfeld, R., Trappe, H., and Gornick, J. (2004). Gender and Work in Germany: Before and After Reunification. Annual Review of Sociology, 30:103-124.

Samuelson, P. A. (1958). An Exact Consumption-Loan Model of Interest with or without the Social Contrivance of Money. The Journal of Political Economy, 66(6):467-482.

Seitz, H. (2006). Zur Quantifizierung des "Korb 2" im Rahmen des Solidarpakts II. ifo Dresden berichtet, $5 / 2006$.

Sinn, H. (2002). Germany's economic unification: an assessment after ten years. Review of International Economics, 10(1):113-128.

Statistische Ämter der Länder (2008). Entstehung, Verteilung und Verwendung des Bruttoinlandsprodukts in den Ländern und Ost-West-Großraumregionen Deutschlands 1991 bis 2007. Reihe 1(Band 5).

Statistisches Bundesamt (2005). Einkommens- und Verbrauchsstichprobe-Aufgabe, Methode und Durchführung der EVS. [Income and Expenditure Survey-task, method and carrying out of EVS]. Fachserie 15, Heft 7.

Statistisches Bundesamt (2007). Volkswirtschaftliche Gesamtrechnungen, Inlandsprodukt nach ESVG 1995, Methoden und Grundlagen. [Overall economic calculations, domestic product according to ESVG]. Fachserie 18, Reihe S. 22.

Statistisches Bundesamt (2009). Bevölkerung Deutschlands bis 2060. 12. koordinierte Bevölkerungsvorausberechnung. [Population in Germany until 2060. 12th coordinated population projection.]. 
Steffen, J. (2002). Die Anpassung der Renten in der Rentenversicherung der Arbeiter und Angestellten. Bremen.

Wagner, I. (2001). Gegenstand und finanzielle Bedeutung des Solidarpakts. ifo Dresden berichtet 2/2001, 3/2001(3):46-53.

Willis, R. (1988). Life cycles, institutions and population growth: A theory of the equilibrium interest rate in an overlapping-generations model. In Lee, R. D., Arthur, W. B., and Rodgers, G., editors, Economics of changing age distributions in developed countries, pages 106-38. Oxford University Press. 